\title{
Faunastic Soil Dwelling Mites of Sugar Beet Fields in Sharkia Governorate, Egypt
}

\author{
H. M. G. El-Kawas \\ Plant Protection Research Institute, A.R.C., Dokki, Giza, Egypt.
}

\begin{abstract}
Twenty one soil mite species belonging to 16 genera of 14 families were collected from soil planted with sugar beet, Beta vulgaris L. in Zagazig district, Sharkia governorate, Egypt. In addition, an identification key for the collected species is provided.
\end{abstract}

Key words: Soil mites; sugar beet; Beta vulgaris L.

\section{INTRODUCTION}

Soil is an important component for monitoring of sustainability of land use in relation to both the conservation of natural resources and biodiversity of ecosystems. So, there has been growing awareness of species diversity and growing interest in understanding the factors influencing soil biodiversity (Ducarme \& Lebrun, 2004). Soil mites often constitute the largest part of soil acarifauna, (Bhattacharya, 1979 and Sanyal \& Bhaduri, 1982). Mite importance in view of ecology and soil fertility is well established (Crossley, 1977 and Heneghan et al., 1998).

In Egypt, sugar beet comes the second sugar crop after sugar cane, Saccharum officinarum L. So, the Egyptian government policy aims to encourage the farmers to increase its cultivation to conserve water and also for its high sugar concentration.

So, it was felt necessary to throw light on soil mites associated with sugar beet in addition to create an identification key for the collected species.

\section{MATERIALS AND METHODS}

The present study was carried out in sugar beet, Beta vulgaris L fields at Zagazig district, Sharkia governorate, Egypt during 2012-13 season. Soil samples were randomly collected every other week during the investigation period. Each sample was around $500 \mathrm{~g}$., collected from the top soil layer $(0-20$ $\mathrm{cm}$.) by iron rectangle $(6 \times 6 \times 8 \mathrm{inch})$.

In the laboratory, mites were extracted using Tullgren's funnel (Lasebikan, 1974). The extracted mites were received in aquatic medium and transferred to solution containing ethanol and acetic acid at 9:1 as sudden death solution, which quickly killed mites and stretched its bodies. After that, mites were transferred to lactic acid as clearing solution for a period depending on mite species and its inflexible degree (El-Moghazy and Shawer, 2013).

The collected mites were singly mounted in Hoyer's medium on glass slides and then examined microscopically. Identification was carried out according to Bregetova (1977); Zaher (1986) and Krantz \& Walter (2009). The collected mite species were deposited as slide mounted specimens in Plant Protection Research Institute (Sharkia branch), Egypt.

\section{RESULTS AND DISCUSSION}

The present study recorded soil mites dwelling in soil cultivated by sugar beet at Zagazig district, Sharkia governorate Egypt, during 2012-13 season. Twenty one mite species belonging to 16 genera and 14 families were recorded.

\section{Superorder: Parasitiformes: \\ Order: Mesostigmata:}

1. Family Laelapidae Berlese:

a. Ololaelaps bregetovae Shereef \& Soliman: Collected from organic manure, Giza; soil of olive orchard, El-Fayoum, (Zaher, 1986).

b. Androlaelaps reticulatus Hafez, El-Badry \& Nasr: Collected from debris; El- Beheira (Hafez, ElBadry \& Nasr, 1982).

\section{Family Ascidae Voigts \& Oudemans:}

a. Proctolaelaps pygmaeus (Müller): Collected from debris under Ucalyptus sp., grapes and tomato; El-Beheira and Benisuef governorates (Zaher, 1986).

b. P. aegyptiaca Nasr: Collected from soil under potatoes and debris under gauva, grapes; Giza, Sohagh and Qena, governorates (Zaher, 1986).

\section{Family Parasitidae Oudemans:}

Schizosthetus lyriformis (McGraw \& Farrier) was observed in the galleries and the bodies of many bark beetle species that inhabit conifers across North America, (McGraw \& Farrier, 1969 and Kinn, 1971).

\section{Family Digamasellidae Evans:}

a. Dendrolaelaps rasmii Nasr \& Mersal: Collected from debris and manures; Giza governorate (Metwally \& Mersal, 1985).

b. D. zaheri Metwally \& Mersal: Collected from manures; Giza governorate (Zaher, 1986). 
II. Superorder: Acariforms:

A. Order: Trombidiforms:

Suborder: Prostigmata:

1. Family Microdispidae Cross:

Brennandania silvestris longisetosa Mahunka:

Firstly recorded in the present study.

\section{Family Pygmephoridae Cross:}

Bakerdania centriger Coor: Firstly recorded in the present study.

\section{Family Scutacaridae Oudemans:}

a. Scutacarus (Variatipes) evansi Soliman \& Kandeel: Collected from soil under the date palm; Giza governorate (Kandeel, 1981 and Zaher, 1986).

b. Scutacarus aegypticus Yousef \& Metwally: Collected from the underground nests of ant, Cataglyphus bicolor Fab. and on the head and thorax regions of the insect.

c. Scutacarus tackei Will.: Firstly recorded in the present study.

d. Scutacarus laetificus Rack: Firstly recorded in the present study.

\section{Family Bdellidae Duges:}

Spinibdella bifurcate Atyeo: Collected from soil, litter, dry leaves and bird nests; Giza governorate, (Zaher, 1986).

\section{Family Cunaxidae Thor:}

Cunaxa sitirostris (Hermann): Collected from mango vegetations; debris and in citrus groves; ElDakahleia; El-Sharkeia and Domietta governorates (Zaher, 1986).

\section{Family Cheyletidae Leach:}

Acaropsellina sollers (Rohdendrof); Collected from soil, debris, stored grains and seeds; Giza, ElMenia and El-Qualyobia governorates (Zaher, 1986).

\section{Family Eupodidae Koch:}

Eupodes temperatus Shib.: Collected from soil under wheat; El-Monofeia governorate (Zaher, 1986).

\section{B. Order: Sarcoptiformes:}

Suborder: Oribatida:

1- Cohort: Brachypylina:

a. Family Oppidae Grandjean:

Multioppia wilsoni Akoi: Collected from soil and debris; BeniSuef and Giza, governorates (Zaher, 1986).

\section{b. Family Oribatulidae Thor:}

Zygoribatula tameyai El-Badry \& Nasr: Collected from soil and truck crops; El-Fayoum, Giza and
BeniSuef governorates (Zaher, 1986).

\section{2- Cohort Astigmatina (Astigmata):}

\section{Family Acaridae Leach:}

a. Tyrophagous putrecentiae (Schrank): Collected from soil and debris under different vegetations and wide spread (Zaher, 1986).

b. Rhizoglyphus robini Claparede: Collected from soil of onion and garlic fields; El-Fayome; Giza; Benisuef; Sohagh and El-Qualyobia, governorates (Zaher, 1986).

The obtained data are in harmony with Norton (1990) who mentioned that Oribatida are one of the most dominant arthropods in the organic horizons of most soils. Also, Krantz and Walter (2009) found that Oribatida was the most abundant soil mites and its individual numbers may be based on host plant. Leetham \& Milchunas (1985) and Zaki (1992) found that distribution of soil mites be affected by two factors which classified into direct and indirect. The direct ones are the enviromental factors and soil quality; while the indirect factors are those corresponding to choice of microhabitate, food, root biomass and the relation between individuals. Abd El-Halim and Rahil (2000) collected 56 mite species inhabiting sugar beet plants and soil; of these 45 species were recorded underneath sugar beet at Fayoum and Beni-Suef governorates, Egypt.

Prostigmata was the most dominant mites, where 18 species belonging to 11 families were recorded, followed by 17 species belong to Mesostigmata. Oribatida included 4 species in 4 families.

Zaher and Mohamed (1980) recorded nine predaceous species of nine families inhabiting sugar beet soil as follows: Hypoaspis sp. (Laelapidae), Rhodacarus sp. (Rhodacaridae), Neognathus sp. (Caligonellidae), Grallacheles bakeri Deleon (Cheyletidae), Cunaxa capreolus (Cunaxidae), Saniosulus nudus Summers (Eupalopsellidae), Rhagidia gelida Thorell (Rhagidiidae), Agistemus exsertus Gonzalez (Stigmaeidae) and Eupodes sp. (Eupodidae).

\section{KEY TO THE COLLECTED SPECIES}

1- With a pair of dorsolateral or ventral stigma at the level of coxae II-IV and associated with a sinanious peritreme. Specialized propodosomal sensory organs and podocephalic canals absent. Coxae free, distinct ................... Superorder Parasitiformes, .............................. Order Mesostigmata ................................. 4

- Without visible stigma. Propodosomal sensory organs, when present, in the form of simple 
sensilla or modified specialized structures in distinctive insertions, with a pair of podocephalic canals often visible. Coxae often fused into ventral body wall often forming coxisternal regions delimited by epimera; number of legs occasionally reduced ... Superorder Acariformes

2

2- Stigma present; usually with distinctive propodosomsl sensory structures ............. 3

- Stigma and tracheal system absent; without distinctive propodosomal structures ........ Order Sarcoptiformes ...... Cohort Astigmatina .... with sejual furrow separating propodosoma from hysterosoma; chelicerae chelate; pedipalp distal segment not flattened; claw supported with two short and thick condylophores and all surrounded by pulvillus; female genital opening without a pregenital sclerite ...... Acaridae ..... 19

3- Stigmatal openings at/or between the bases of the chelicerae, the base of the gnathosoma or on the anterior propodosomal shoulders. Empodial elemnts of legs II \& III commonly pad-like, rayed or broadly membranous ... Order Trombidiformes ...... Suborder Prostigmata

10

- Stigmatal opening in the acetabular cavities of legs I \&I II, on the legs themselves or through the sensillus. Usually with three pairs of genital discs. True claws generally present. Empodium claw-like, with four pairs of genital setae ...... .......... Order Sarcoptiformes ...... Suborder Oribatida 20

4- Dorsal plate undivided; body dorsum with 39 pairs of setae; genital shield narrow, tongue or flask-like or inflated to form opsthomogenital shield ........................ Laelapidae ........5

- Dorsal plate entire or more usually divided into two parts; genital shield not as above

5- Female with anal shield fused with genitovental shield; metasternal setae on sternal shield, apotele with three unqual prolongs ...... Ololaelaps Berlese ...... Dorsal shield nearly covers the reticulated idiosoma; with 39 pairs of simple setae plus an unpaired seta between J series; genitovental shield reticulate, expanded conspicuously behind coxae IV, and with six pairs of simple setae plus three short anals; metapodal plates elongate

O. bregetovae Shreef \& Soliman

- Female with anal shield free; metasternal setae not in sternal shield; genu IV with 10 setae ( $\mathrm{pl}_{2}$ present), pilus dentilis long, slender or inflated ......................... Androlaelaps Berlese ............. Dorsal shield reticulate; with 39 pairs of simple setae; podonotum with 22 pairs; genital shield weakly sclerotized, not expanding posteriorly to anterior margin of anal shield; endopodal and metapodal plates small A. reticulatus Hafez, El-Badry \& Nasr

6- Dorsal plate divided into an anterior and a posterior section of approximately equal dimensions; tectum never a single, elongate with denticulate process ............. Ascidae ....... Adults with holodorsal shields; fixed chela with membranous lobe in place of pilus dentilis, movable digit usually with a ventral macro; female with genital shield rounded posteriorly; anal shield with anal setae only .......................... Proctolealps Berlese.... . 7

- Dorsal plate divided into two sections (or sometimes entire); tectum triramous or tridentate $\ldots \ldots \ldots \ldots \ldots \ldots \ldots \ldots \ldots \ldots \ldots \ldots . . .6$

7- Seta $\mathrm{j}_{5}$ about half length $\mathrm{j}_{4}$; setae $\mathrm{j}_{2}, \mathrm{z}_{2}, \mathrm{~s}_{1}, \mathrm{~s}_{2}$ and $\mathrm{r}_{2}$ slightly shorter than $\mathrm{r}_{3} \ldots . . P$. pygmaeus (Müller)

- Seta $\mathrm{j}_{5}$ minute; setae $\mathrm{j}_{2}, \mathrm{z}_{2}, \mathrm{~s}_{1}, \mathrm{~s}_{2}$ and $\mathrm{r}_{2}$ much shorter than $r_{3} \ldots \ldots \ldots \ldots . . . \ldots \ldots \ldots . .$. . aegyptiaca $\mathrm{Nasr}$

8- Dorsal plate entire, or with podonotal and opisthonotal shield; tectum basically tridentate ........... Parasitidae ............. Cingulum of female narrow; glands $\mathrm{gdz}_{5}$ present, glands $\operatorname{gdR}_{3}$ not on opisthosomal shield; seta $\mathrm{Sv}_{1}$ present,; ventrianal shield with 8 setae; tarsi II of male with seta $\mathrm{pv}_{1}$ spine-like, seta $\mathrm{av}_{1}$ simple ....... ..... Schizosthetus lyriformis (McGraw \& Farrier)

- Dorsal plate completely divided into two parts (in deutonymphs and adults); with podonotal shield usually with four oval or comma-shape refractive nodules between setae $\mathrm{j}_{5}$ and $\mathrm{j}_{6} . . . . . . . . . . .$. Digamasellidae ........... Adults with two pairs of light refractive structures between setae $\mathrm{z}_{5}$; podonotal shield with setae $\mathrm{z}_{3}$; anal opening normal ; femur II with eleven setae ; hypognathal groove with five rows of denticles, proximal row wider than others

$$
\text { Dendrolaelaps Halbert . }
$$

9- Opisthonotum with 19 pairs of setae (J, Z, S series and $\left.\mathrm{R}_{2-} \mathrm{R}_{5}\right) \ldots \ldots \ldots \ldots . .$. D. rasmii Nasr \& Mersal - Opisthonotum with 15 pairs of setae (J, Z, S series only), setae $R_{2}-R_{5}$ off shield; podonotum with 21 pairs of setae $\left(j, z, s\right.$, series and $\left.r_{2}, r_{4}, r_{5}\right) \ldots \ldots$ D. zaheri Metwally \& Mersal

10- Gnathosoma usually circular in outline, with minute palpi and chelicerae. Stigma of female opening on propodosoma behind and lateral to gnathosomal base; males without stigma or trachea .................................. 11

- Gnathosoma generally conspicuous, with distinct chelicerae and developed palpi. Stigmatal opening 
at base of chelicerae 16

11- Legs IV of female with claws and membranous empodia; tarsus of leg I with a single claw or without claws .................................. 12

- Legs IV of female with claws and empodia; tarsus of leg I without claws or empodia

........... Microdispidae ........ Tergite PS with two pairs of setae ; anterior sternal plate with four pairs of setae; posterior sternal plate with two pairs of setae; dorsal setae finly barbed; one pair of propodosomals present; seta d hardly reaching alveoli of seta $f$, seta $h_{1}$ long; leg I four segments, femur I with 3 setae of which seta c simple; sensillus oval with short stalk

.... Brennandania silvestris longisetosa Mahunka

12- Propodosoma always free, bearing 2-3 pairs of setae .... Pygmephoridae..... Tergite PS with three pairs of subequal setae; anterior sternal plate with four pairs of setae; posterior sternal plate with five short pairs of setae; leg I with four segments, femur I with three setae of which c short, tibiotarsus I with a short claw; tergite $\mathrm{C}$ with seta $c_{1}$ not reaching alveolus of seta $d$; setae $\mathrm{h}_{1}, \mathrm{~h}_{2}$ of same length

Bakerdania centriger Coor

- Propodosoma usually covered by a very large clypeus with $1 / 2$ a wide striated free margin, bearing at least a pair of setae in humeral position Scutacaridae 13

13- Dorsal hysterosomal setae long, each surpassing the alveoli of setae located on the next segment, arising on tubercles except those on the clypeus ; most of ventral setae long and barbed ; tibiotarsus of leg I without claw .................... Scutacarus (Variatipes) evansi Soliman \& Kandeel

Dorsal hysterosomal setae short, arising on normal alveoli; most of ventral setae short, simple; tibiotarsus of leg I with or without claw 14

14- Dorsal hysterosomal setae clyndrical; tibiotarsus of leg I terminates with a short claw, bears solenidion $\mathrm{w}_{1}$, short and rod-like Scutacarus aegypticus Yousef \& Metwally

- Dorsal hysterosomal setae simple; tibiotarsus of leg I without claw .15

15- Setae poststernales internae long, reaching vulva; setae axillares conspicuously long extending also beyond vulva; five pairs of setae arise on tergites I-IV Scutacarus tackei Will

- Setae poststernales internae short, not reaching vulva; setae axillares short, not reaching vulva also; eight pairs of setae arise on tergites
I-IV Scutacarus laetificus Rack

16- Cheliceral bases fused or not, not capable of a lateral scissor-like motion over gnathosoma .................................. 18 - Cheliceral bases not fused, the chelicerae moving scissor-like motion over gnathosoma, anterior portion of gnathosoma reduced into a long "snout" with two pairs of long sensory setae, or sensilla on the propodosoma

17- With 3 pairs of genital discs; palpi long, often elbowed, usually with strong distal antenniform setae ............. Bdellidae ............ Hypostome ventrum with two pairs of setae; chelicerae elongate; chela needle-like; hypostome and chelicerae with two pairs of setae and longitudinal striations; propodosomal dorsum with two pairs of eyes and four pairs of setae; posterior sensillum longer than anterior one; lateral propodosomal setae shorter than median one .................. Spinibdella bifurcrta Atyeo

- With 2 pairs of genital discs (rarely 3 or 4 pairs); palpi extending beyond gnathosoma, or shorter and approximately equal to the chela in length, adapted for grasping .................. Cunaxidae .... Hysterosoma without shields, with a pair of lateral and five pairs of dorsolateral setae; palp with five segments, $1 \frac{1}{2}$ times length of cone-shape hypostome, third palpal segment (telofemur) with a strong spine and a spur or apophyses; chelicerae with fine punctations basally; an obvious neck between gnathosoma and idiosoma; propodosomal shield reticulate medioposteriorly; hysterosoma without shield, with a pair of minute setae posteriorly ....................... Cunaxa sitirostris (Hermman)

18- Chelicerae and rostrum fused into a cone ; palpi with comb and sickle-like setae ..... Cheyletidae Humeral seta $\mathrm{C}_{2}$ filliform, much longer than dorsal setae; palp femur shorter than dorsofemoral setae ; agenital setae twice as long as genital setae . Acaropsellina sollers (Rohandro.)

- Chelicerae with shears, small and sometimes distored; propodosomal anterior portion with tubercle bearing a pair of setae ...... Eupododidae ..... Propodosoma with small rounded epivertex, with two setae of which the internal verticals situated on the epivertex; a suture present between propodosoma and hysterosoma; dorsal body setae, paragenitals and second anal setae not swollen; dorsal ciliated setae long, surpassing bases of succeeding setae ; paraginital setae 7+7 ; anal pore with three pairs of anal setae Eupodes temperatus Shiba

19- External verticals (ve) usually more than half 
length of internal verticals (vi), seta (ve) at level posterior to (vi) ; seta $\mathrm{d}_{2}$ about two times as long as $\mathrm{d}_{1}$; tarsus IV subequal to sum of tibia and genu Tyrophagous putrescentia (Shrank)

- External verticals (ve), setae he, $d_{3} ; d_{4}$ and sci long, other setae short; tarsus IV with two suckers Rhizoglyphus robini Claparede

20- Legs monodactylous; with 9-12 pairs of notogastral setae; 4-9 pairs of genital setae; prodorsal lamellae absent .............. Oppiidae

Body elongate oval, brown reddish; prodorsum elliptical ; rostral setae slightly larger than lamellers; all prodorsum setae uniciliate; sensillus clavate and covered with long hairs; notogaster elliptical, with 12 pairs of subequal unibarbed setae; fissure (im) distinct ................... Multioppia wilsoni Aoki

- Legs tridactylous ; with 11-14 pairs of notogastral setae; 4 pairs of genital setae; lamella ribbonshape ........... Oribatulidae ...... Body broadly ovate with tapered posterior end, light brown in colour; prodorsum triangular; rostral setae smaller than lamellers; all prodorsum setae pilose; sensillus with sub-spherical head and covered with fine hairs; notogaster pear shape, with a pointed posterior and a transferse suture dividing the notogaster into two unequal sections just posterior to fissure (im), with multidifficient setal pattern, as it bears eleven pairs of subequal and pilose setae ........ Zygoribatula tameya El-Badry \& Nasr

\section{ACKNOWLEDGMENTS}

The author is most grateful to Dr. M.M.H. Kandeel (Professor of Zoology, Faculty of Technology and Development, Zagazig University, Egypt) for the identification of the collected mites and for his kind review of the manuscript.

\section{REFERENCES}

Abd El-Halim, S.M. and Rahil, A.A.R. 2000. Incidence of mites inhabiting leaves and soil of sugar beet at Fayoum and Beni-Suef governorates, Egypt. J. Agric. Sci. Mansoura Univ., 25(11): 7159-7169.

Bhattacharya, T. 1979. Climate, soil and soil inhabiting arthropods of Shantiniketan and Adjoining Ares. J. of Res. m Visa-Bharati, 3(2): 12-23.

Bregetova, N.G. 1977. Identification key of soil inhabiting mites mesostigmata. Nauka, Leningrad: $717 \mathrm{pp}$.

Crossley, D.A. Jr. 1977. The roles of terrestrial saprophagous arthropods in forest soils: current status of concepts. In: Proceedings in Life
Sciences: The Role of Arthropods in Forest Ecosystems, (W. J. Mattson ed.) Springer-Verlag, New York: 49-56.

Ducarme, X. and Lebrun, P. 2004. Spatial microdistribution of mites and organic matter in soils and caves. Biol. Fertil. Soils, 39: 457- 466.

El-Moghazy, M.M.E. and Shawer, S.S. 2013. Relationship between soil diversity and inhabitant mites (Acari). Acarines, 7: 41-45.

Hafez, S.M.; El-Badry, E.A. and Nasr, A.K. 1982. Soil mites of the family Laelapidae from Egypt (Acari: Mesostigmata). Res. Bull. Fac. Agric. Ain Shams Univ.: 1-15.

Heneghen, L.; Coleman, D.C.; Crossley, D.A. Jr. and Hainese, B.L. 1998. Soil microarthropod community structure and litter decomposition dynamics: A study of tropical and temperate sites. Applied Soil Ecology, 9: 33-38.

Kandeel, M.M.H. 1981. Ecological and biological studies on some tarsonemid mites. Ph.D. Thesis, Fac. Agric., Cairo Univ., 307 pp.

Kinn, D.N. 1971. The life cycle and behavior of Cercoleipus coelonotus (Acarina: Mesostigmata) including a survey of phoretic mite associates of California Scolytidae. University of California Publication in Entomology, 65: 1-59.

Krantz, G.W. and Walter, D.E. 2009. A manual of acarology, $3^{\text {rd }}$ ed. Texas Tech University Press; Lubbock, Texas: 807 pp.

Lasebikan, B.A. 1974. A preliminary communication on microarthropods from a tropical rain forest in Nigeria. Pedobiologia, Jena, 14: 402-411.

Leetham, J.W. and Milchunas, D.G. 1985. The composition and distribution of soil microarthropods in the shortgrass steppe in relation to soil water, root biomass and grazing by cattle. Pedobiologia, 28: 311-325.

Metwally, A.M. and Mersal, R.R. 1985. Two new species of Dendrolaelaps Halbert., with description of their immature stages (Mesostigmata: Digamasellidae). $1^{\text {st }}$ Nat. Conf. of Pests and Dis. of Veg. \& Field crops in Egypt, Ismailia: 153-167.

McGraw, J.R. and Farrier, M.H. 1969. Mites of the superfamily Parasitoidea (Acarina: Mesostigmata) associated with Dendroctonus and Ips (Coleoptera: Scolytidae). North Carolina Agriculture Experiment Station Technical Bull., 192: 1-162.

Norton, R.A. 1990. Acarina: Oribatida. In: Dindal, D.L. (Ed.), soil biology Guide. Wiley, New York, pp.779-803.

Sanyal, A.K. and Bhaduri, A.K. 1982. Seasonal changes in the density of soil oribatid mites in relation to temperature and water content of soil at Sagar Island, 24-Parganas, West Bengal. Proc. Symp. Ecol. Anim. Popul. Zool. Surv. India, 
3: 119-126.

Yousef, A. A. and Metwally S. H. 1973. A new species of the genus Scutacarus (Acarina: Scutacaridae) in Egypt. Acarologia, 15(3): 457-460.

Zaher, M.A. and Mohamed, M.I. 1980. Mites associated with sugar beet in Egypt. Ann. of Agric. Sc., Moshtohor, 13: 205-207.

Zaher, M.A. 1986. Predaceous and Nonphytophagous
Mites (Nile Valley and Delta). Text. Survey and Ecological Studies on Phytophagous, Predaceous and Soil Mites in Egypt. Egypt, PL 480 Programme USA, Project EG-ARS-30, Grant No. FG-EG-139. 567pp.

Zaki, A.M. 1992. Population dynamics of soil mites associated with some stone fruit trees in Menoufia, Egypt. Acta Phytopathologica et Entomologica Hungarica, 27(1-4): 679-685. 